\title{
Formation and structure of the turbidity maximum in the macrotidal Charente estuary (France): influence of fluvial and tidal forcings
}

\author{
F. Toublanc ${ }^{\mathrm{a}, *}$, I. Brenon $^{\mathrm{a}}$, T. Coulombier ${ }^{\mathrm{a}}$ \\ ${ }^{a}$ UMR 7266 LIENSS CNRS-University of La Rochelle, 2 rue Olympe de Gouges, 17000 La Rochelle, France
}

\begin{abstract}
Understanding estuarine sediment dynamics, and particularly turbidity maximum dynamics, is crucial for the management of these coastal systems. Various processes impact the formation, movement and structure of the turbidity maximum. Several studies have shown that tidal asymmetry and density gradients are responsible for the presence of
\end{abstract} this suspended sedimentary mass.

The Charente estuary is a highly turbid system (with suspended sediment concentrations mostly in excess of 5 $g / L$ ) that remains poorly understood, despite its strong impact on local activities. In this study, a three-dimensional hydrosedimentary model is developed to represent the sediment dynamics of this estuary. Model validation demonstrates good accuracy, especially on reproducing semi-diurnal and spring-neap variability. Several simulations are performed to evaluate the influence of tides and river discharge on the turbidity maximum. Mean and maximum suspended sediment concentrations $(S S C)$ and sediment stratification, are calculated. $S S C$ transects are also used to visualise the suspended sediment distribution along the estuary.

The turbidity maximum generally oscillates between the river mouth and the Rochefort area (20-30 km upstream). The model shows strong variations at different time scales, and demonstrates that $S S C$ is mainly driven by deposition/resuspension processes. Spring-neap comparisons show that the turbidity maximum is not well-defined during neap tides, for low and mean runoff conditions. Simulations of spring tides and/or high runoff conditions all result in a compact suspended sedimentary mass.

Performing simulations without taking density gradients into account demonstrates that tidal asymmetry is the main mechanism leading to the formation of the turbidity maximum. However, density gradients contribute to maintaining the stability of the turbidity maximum. Vertical stratification traps sediments at the bottom. Longitudinal stratification ensures a sharper edge at the downstream limit of the suspended sedimentary mass, preventing a massive export of sediments.

Keywords: Estuary, Turbidity maximum, Numerical Modelling, Sediment dynamics, Tidal asymmetry, Density gradient

\footnotetext{
${ }^{*}$ Corresponding author

Email address: florence.toublanc@univ-lr.fr (F. Toublanc)
} 


\section{Introduction}

Because of their unique location at the interface between land and sea, estuaries are critical ecosystems subject to strong anthropogenic pressures. Macrotidal estuaries characterized by the presence of fine cohesive sediments frequently exhibit the formation of a highly turbid zone. This compact suspended sedimentary mass is called a turbidity maximum, and it is sensitive to variations in the tidal and fluvial regime. Understanding the dynamics and characteristics of turbidity maxima is important for the ecology as well as the economy of nearby coastal areas. For example, fine cohesive sediments are noted carriers of pollutants that endanger water quality (Eyre and McConchie, 1993). They are also related to strong siltation rates near harbours or other infrastructure, necessitating regular dredging. For instance, Owens et al. (2005) report that $50 \times 10^{6}$ tons/year of sediment are dredged from coastal areas in the UK. They also show that dredging reaches 4 to $5 \times 10^{6} \mathrm{~m}^{3} /$ year in the Elbe river and Hamburg harbour in Germany.

Turbidity maximum processes have been studied in several estuaries (Allen et al., 1980; Brenon and Le Hir, 1999; Cancino and Neves, 1999; Dyer, 1997; Sottolichio et al., 2000; Uncles and Stephens, 1993; Uncles et al., 2006). The suspended sediment concentration in the turbidity maximum varies on several time scales (following the ebb-flood cycle, spring-neap cycle, seasonal variations, and so forth). On the $12 \mathrm{~h}$ scale of a semi-diurnal tidal cycle, slack waters tend to favour sedimentation and deposition, whereas flood and ebb phases favour erosion and resuspension, with mobile bed sediments feeding the turbidity maximum (Allen et al., 1980). Fluctuations on the larger time scale of a spring-neap tidal cycle, induced by changes in the current velocities intensities, are also important (Allen et al., 1980; Dyer, 1997). From spring to neap tides, current velocities decrease and sedimentation takes place. The turbidity maximum zone is then reduced, and fluid mud appears (or is supplemented) at the bottom. Seasonal variations related to river discharge also occur. For example, floods can induce a seaward movement of the turbidity maximum (Allen and Castaing, 1973; Uncles et al., 2006).

The formation of a turbidity maximum in an estuary is mainly attributed to two processes: density circulation and tidal asymmetry (Allen et al., 1980). Density gradients may generate two-layer circulation (density circulation), with freshwater moving seaward at the surface and saltwater moving landward at the bottom. A turbidity maximum can appear at the density nodal point, where the flow becomes entirely seaward-oriented (Allen et al., 1980; Dyer, 1997). Tidal asymmetry, characterized by uneven current velocities and slack waters (Aubrey and Speer, 1985; Friedrichs and Aubrey, 1988), can generate a turbidity maximum at the tidal nodal point. According to Allen et al. (1980) and Dyer (1997), the tidal nodal point is often located upstream from the density nodal point. Uncles and Stephens (1993) showed that positions of the turbidity maximum sometimes corresponds to the freshwater-saltwater interface.

The relative importance of both processes depends on estuary characteristics. Li (1994) suggested that turbidity maximum dynamics are mainly driven by the tides. This behaviour was confirmed by Brenon and Le Hir (1999) and Sottolichio et al. (2000) in the Seine and Gironde estuaries, respectively. However, both studies showed that density gradients are essential to the stability of the turbidity maximum by maintaining a compact sedimentary mass in suspension and preventing strong sediment export. 
The Charente estuary (Figure 1), located on the French Atlantic coast, is a useful site in which to study estuarine dynamics. In the recent years, the area has experienced droughts and also hosts a broad spectrum of economic activities (oyster farming, agriculture, tourism, port operations, and so forth), making this estuary particularly sensitive to water quality and siltation issues. Local features, such as the inversion of tidal asymmetry as a function of the spring-neap tidal cycle (Toublanc et al., 2015) are also interesting. More generally, although numerous studies have investigated large macrotidal estuaries, smaller systems such as the Charente remain poorly understood. However, many of these small estuaries strongly influence their surroundings. This study focuses on the turbidity maximum and suspended sediment dynamics in the Charente, at different time scales and under various fluvial and tidal regimes. Several indicators are used to quantify the impact of these forcings on the horizontal and vertical distribution of $S S C$ (suspended sediment concentration), and to identify the mechanisms that drive the formation of the turbidity maximum. Changes in its structure are also investigated numerically, to delineate the processes controlling sediment escape to the connected bay.

\section{Study site}

The Charente estuary $\left(45^{\circ} 96 \mathrm{~N}, 1^{\circ} 00 \mathrm{~W}\right.$, Fig. 1) is located on the French Atlantic Coast. The river flows into the Marennes-Oléron Bay, in the southern part of the pertuis Charentais. The river's catchment is $10550 \mathrm{~m}^{2}$ and its length is $365 \mathrm{~km}$. A dam is located in Saint-Savinien, $50 \mathrm{~km}$ from the river mouth. The mean river discharge is estimated to be $70 \mathrm{~m}^{3} / \mathrm{s}$. Discharge can reach extreme values of 600 to $700 \mathrm{~m}^{3} / \mathrm{s}$ during flood events, and drop to less than 10 $\mathrm{m}^{3} / \mathrm{s}$ during the summer. Exceptional floods can have caused discharges of up to $1000 \mathrm{~m}^{3} / \mathrm{s}$. The river is shallow, with a maximum depth of $10 \mathrm{~m}$ below mean sea level, and the estuary mouth is funnel-shaped.

The Marennes-Oléron Bay's total surface area covers nearly $150 \mathrm{~km}^{2}$, with $60 \%$ composed by intertidal areas. The sediments in the estuary and in the eastern part of the Marennes-Oléron Bay are entirely cohesive, with a very fine grain size (Strady et al., 2011). In the western part of the bay, sediments are sandier (Tesson, 1973; Bertin et al., 2005). The mud ratio decreases and the mean gran size tends to increase upstream, but the latter remains less than 20 $\mu m$ and the mud ratio is always greater than $80 \%$ (Coulombier et al., 2013).

The estuary and the bay are affected by semidiurnal tides. At the river mouth, the mean and maximum tidal ranges are $4.5 \mathrm{~m}$ and $6.5 \mathrm{~m}$, respectively. This macrotidal regime is also characterized by the influence of quarterdiurnal constituents (M4, MS4 and MN4), which are strongly amplified shoreward by resonance along the Bay of Biscay shelf (Le Cann, 1990). Bertin et al. (2012) verified this phenomenon numerically and showed that the largest amplification by resonance occurred for the MS4 constituent. In combination with the internal tidal distortion of the estuary, these externally generated overtides result in fortnightly inversions of the tidal asymmetry (Toublanc et al., 2015). Depending on the timing of the spring-neap tidal cycle, and the position in the estuary, the estuary can be dominated either by the flood or the ebb.

Prior to this study, few data were available on the turbidity maximum of the Charente estuary, including only 


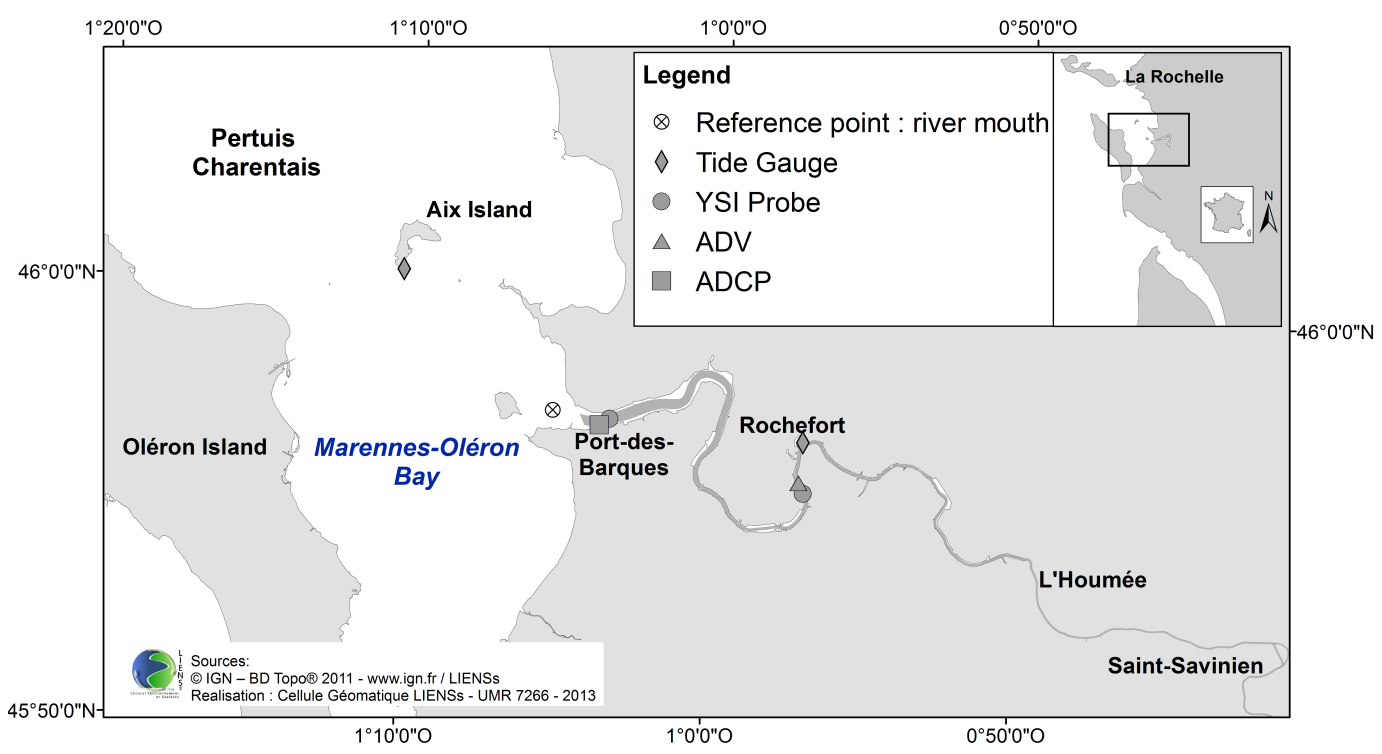

Figure 1: The Charente River, from the Saint-Savinien dam to the mouth, including locations of sampling stations

intermittent observations and no numerical modelling. Ravail et al. (1988) recorded $S S C$ up to $10 \mathrm{~g} / \mathrm{L}$ at the river mouth, Auguet et al. (2005) measured concentrations greater than $5 \mathrm{~g} / \mathrm{L}$ at the surface in Rochefort. Local actors often reported strong suspended sediment concentrations around Rochefort (20 km upstream from the mouth): bathymetric surveys performed by public services revealed at several occasions the presence of a highly concentrated suspended sedimentary mass in front of the Rochefort harbour. Schmidt et al. (2010) and Le Moine et al. (2012) reported the presence of fluid mud in the proximity of the Saint-Savinien dam. Despite these observations, the spatio-temporal evolution of the turbidity maximum has not been studied yet in the Charente estuary.

The characteristics and movements of the turbidity maximum are very important to management of the area. This is especially true in Rochefort where the harbour is often dredged to compensate for strong sediment accumulation: reports estimate that $160,000 \mathrm{~m}^{3} /$ year of sediment is dredged. Tourism, as well as oyster and mussel farming in the Marennes-Oléron Bay also strongly depend on outflows from the Charente river.

\section{Materials and methods}

\subsection{Numerical modelling}

The numerical model MARS-3D (Modelling for Applications at Regional Scales) used in this study has been described in previous work (Lazure and Dumas, 2008). It is a finite differences model that solves the Navier-Stokes equations under hydrostatic and Boussinesq assumptions when used in 3D mode. 


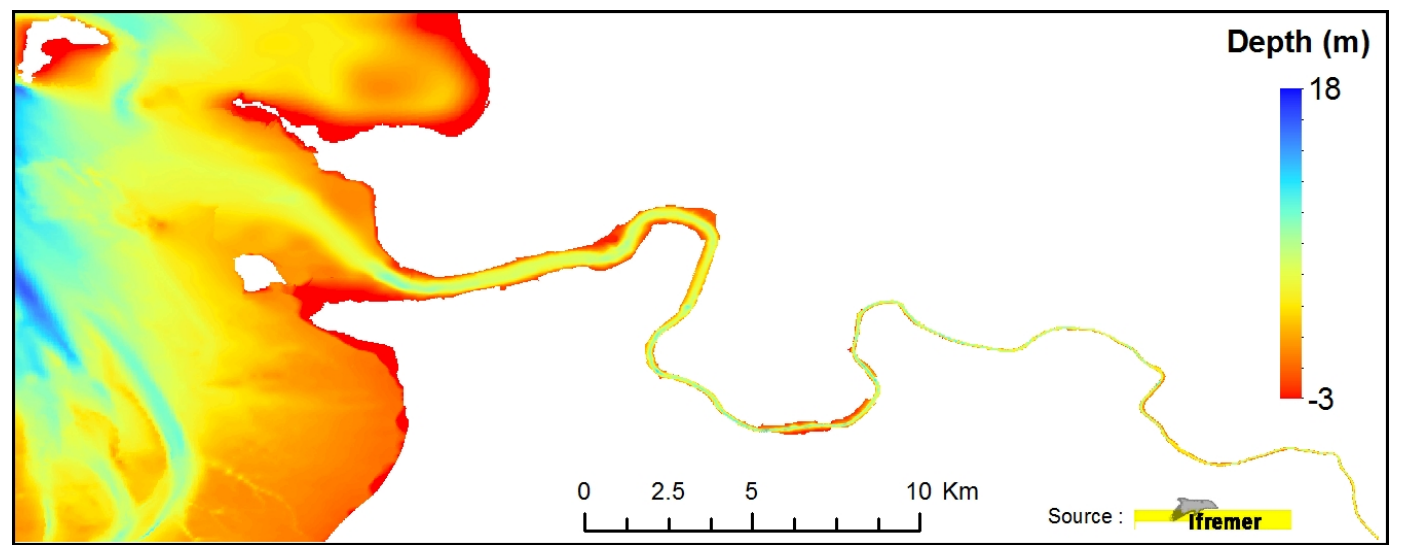

Figure 2: Bathymetric data used for numerical modelling

The configuration presented here consists of two nested grids. The first one, with $100 \mathrm{~m}$ horizontal resolution, is forced by tides computed using the SHOM CST-France model (Le Roy and Simon, 2003). It runs in 2D and provides open boundary conditions at the seaward limit for the second grid. This grid has a $30 \mathrm{~m}$ horizontal resolution and runs in 3D with 8 sigma levels. Daily river discharges are prescribed. Bathymetric data (Fig. 2) were provided by several organizations (SHOM, Ifremer, EPTB Charente). Upstream of L'Houmée, the grid resolution is insufficient to accurately represent the dynamics of the river. Consequently, an artificial canal is created, with bathymetric values extracted from the real data. This allows us to prescribe the estimated daily discharge at the Saint-Savinien dam.

Atmospheric forcing is provided by the ARPEGE model from Météo-France(15 kilometres, 6 hours). The model includes the wind speed 10 meters above the sea surface, the atmospheric pressure and the temperature 2 meters above the sea surface.

A two equation k-kl turbulence closure model is used (Warner et al., 2005b). This model, which resembles the Mellor-Yamada level 2.5 scheme $(1974 ; 1982)$, solves the vertical eddy viscosity and diffusivity by calculating the turbulent kinetic energy and the turbulence length scale. The horizontal eddy viscosity and diffusivity are computed by using the Smagorinsky method, to take the local shear conditions into account (1963).

Considering the relative homogeneity of the sediment and its granulometry measured along the estuary, one sedimentary class is used in the model. Settling velocity is variable (between 0.05 and $1 \mathrm{~mm} / \mathrm{s}$ ) and depends on concentration, salinity and turbulence, according to a semi-empirical formulation (Le Hir et al., 2001). The concentration and turbulence dependence for settling is crucial to take into account the flocculation processes that occur in areas of strong SSC with cohesive sediment (Blake et al., 2001; Milligan et al., 2001, 2007). The sedimentary module mudsand in MARS-3D was fully described by Le Hir et al. (2011) and takes into account suspended sediment transport (no bedload transport) associated with fine sediments. Consolidation processes are not considered in this study. In the absence of relevant measurements at the Saint-Savinien dam that would allow us to establish a runoff/concentration relationship, a fixed input of $0.05 \mathrm{~g} / \mathrm{L}$ is prescribed at the upstream boundary. This value was chosen according to 
upstream data presented by Modéran et al. (2012). Moreover, cores and surface sediments sampled on the estuarine banks show little variation in the mud fraction and mean grain size. Thus, variations in river flow do not necessarily imply a strong fluvial sediment input, because the sediment characteristics remain very similar.

\subsection{In-situ measurements for model validation}

Model validation is performed using in-situ data recorded for different periods and at different locations, as shown in Figure 1.

Sea surface elevation and current velocities are validated using continuous tide gauge data from Rochefort and the Aix Island (from the REFMAR portal) and ADCP data (Sentinel-RDI instruments, $1200 \mathrm{kHz}$, 5-minute sampling frequency, February to April 2011) at the river mouth (Port-des-Barques). Current velocities are also validated using ADV measurements (Argonaut-ADV, Sontek) carried out at Rochefort (November 2012 to August 2013, 30 seconds averaged every 5 minutes), approximately one meter above the sediment bed.

Simulated salinity levels are compared to datasets obtained from multi-parameter probes (YSI 6600V2) located at the mouth, surface (February to March 2011, 10-minute sampling frequency) and bottom (October to December 2012, 5-minute sampling frequency). Turbidity data were also recorded with the same probes (5-minute sampling frequency), at the mouth (approximately two meters above the bed) and at Rochefort (approximately one meter above the bed). Salinity and turbidity probes were laboratory calibrated using standard solutions (12880 microS iemens.cm ${ }^{-1}$, and formazin at 1000 and 4000 NTU, respectively). Wet sediments collected from the intertidal banks of the Charente were diluted at several concentrations in a $40 \mathrm{~L}$ black bucket to calibrate the turbidity sensors. Validation of suspended sediment concentrations was performed after filtration on GF/C filters (Coulombier et al., 2013).

\section{Results}

This section focuses on the results obtained by numerical modelling. The $S S C$ levels are analysed and displayed for various fluvial and tidal conditions. Prior to this analysis, the performance of the model is validated to several variables (water surface elevation, current velocities, salinity levels and $S S C$ ).

\subsection{Model validation}

Mean absolute (MAE) and root mean square (RMSE) errors are calculated to compare the modelled and observed water surface elevation, current velocities and salinity levels. Model accuracy is also evaluated using the skill parameter (Eq. 1) developed by Willmott (1981) and used in several recent estuarine dynamics studies (Li et al., 2005; Ma et al., 2011; Warner et al., 2005a; Xing et al., 2012). This parameter takes into account the modelled $\left(X_{m o d}\right)$ and observed $\left(X_{o b s}\right)$ deviations around the observed mean $\left(\overline{X_{o b s}}\right)$ to estimate model performance, and varies between 0 (no agreement) and 1 (perfect agreement), as follows: 


$$
\text { Skill }=1-\frac{\Sigma\left|X_{m o d}-X_{o b s}\right|^{2}}{\Sigma\left(\left|X_{\text {mod }}-\overline{X_{o b s}}\right|+\left|X_{o b s}-\overline{X_{o b s}}\right|\right)^{2}}
$$

All calculations are presented in Table 1. The stations used for validation are shown in Figure 1.

Table 1: Model - data comparison calculations for water surface elevation, current velocities and salinity

\begin{tabular}{c|c|ccc}
\hline Variable & Location & MAE & RMSE & Skill (no unit) \\
\hline Water surface elevation & Aix Island & 9.92 & 12.3 & 0.9974 \\
$(\mathrm{~cm})$ & Port-des-Barques & 12.66 & 15.38 & 0.9976 \\
& Rochefort & 13.26 & 16.73 & 0.9969 \\
\hline Current velocities (u;v) & Port-des-Barques (averaged) & $12.4 ; 7.06$ & $16.2 ; 8.78$ & $0.9802 ; 0.9344$ \\
$(\mathrm{~cm} / \mathrm{s})$ & Rochefort (bottom) & $10.04 ; 12.47$ & $12.48 ; 15.79$ & $0.9255 ; 0.9473$ \\
\hline Salinity & Port-des-Barques (surface) & 2.71 & 3.39 & 0.9708 \\
$(\mathrm{psu})$ & Port-des-Barques (bottom) & 1.91 & 2.26 & 0.9620 \\
& Rochefort (bottom) & 2.23 & 2.75 & 0.9506 \\
\hline
\end{tabular}

Water surface elevations are well reproduced by the model (skill $>0.99$ for all locations). Figure 3 shows a graphical representation of the results at the estuary mouth and at Rochefort. A period of two tidal cycles (24 h) is shown for the water surface elevation at Port-des-Barques, close to the estuary mouth.

In MARS-3D, bottom friction is calculated using a roughness length $z 0$, derived from the Nikuradse coefficient (Nikuradse, 1950). The hydrodynamic results showed in Figure 3 and Table 1 required adjusting this parameter, which was reduced within the estuary. This issue was particularly important in the Rochefort area, because of fluid mud in the channel, which can cause a significant increase in current velocities, the physical roughness of the sediment bed being very low. Hamm and Walther (2009) and Walther et al. (2007) showed that hydrodynamic models often fail to reproduce this effect and overestimate low water levels. King and Wolanski (1996) made similar observations. After calibration of our model, the Chézy coefficient corresponding to the roughness length is estimated to reach 100 to 110 $\mathrm{m}^{1 / 2} / \mathrm{s}$, depending on the water depth. These values are within the range of those obtained in other studies: according to Winterwerp and Van Kesteren (2004), Chézy values of $110 \mathrm{~m}^{1 / 2} / \mathrm{s}$ were found in the Yangtze and the Amazon rivers, due to the presence of fluid mud.

Current velocities are better reproduced in the direction of flow (zonal in Port-des-Barques, meridional in Rochefort (Figure 3)) than in the perpendicular direction. However, the model still agrees well with observational data (skill > 0.92). The highest errors occurred at Rochefort, both for current velocities and water surface elevation. Model performance on salinity is within the range of the two previous parameters (skill $>0.95$ ). Errors mainly occur during the transition from spring to neap tide (and vice versa).

Concerning sediment dynamics, French (2010) noted that it was difficult to validate modelled suspended sediment 

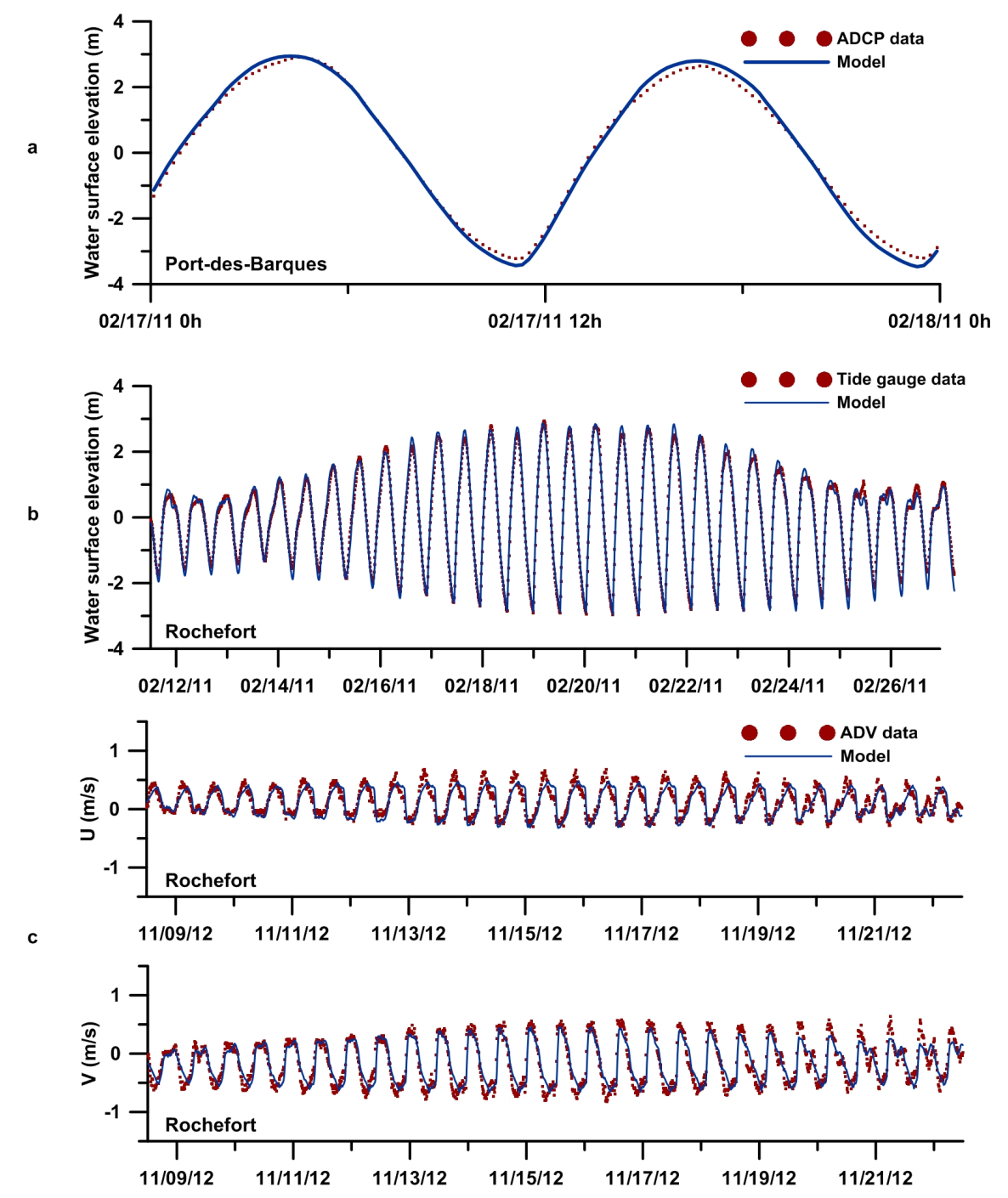

Figure 3: Measured and modelled water surface elevations at the river mouth (Port-des-Barques) over $24 \mathrm{~h}$ (a) and at Rochefort over 14 days (b). Measured and modelled current velocities at Rochefort (c) 
concentrations, compared to tidal levels and velocities. This difficulty arises from the complexity inherent in the large parameter sets of suspended sediment models. A brief description of the sediment module in MARS-3D is available in the appendix, and demonstrates that there are a lot of variables to take into account and to calibrate. In the Charente estuary, this difficulty was enhanced by the high levels of turbidity observed. Over 4000 NTU, turbidity sensors saturate and fail to properly measure sediment concentrations. Validation is thus impossible with classical parameters such as MAE and RMSE. Nonetheless, a series of tests was conducted to calibrate the model with data comparisons from two locations: Port-des-Barques and Rochefort (not shown). Several parameters were adjusted including the minimum and maximum settling velocities, the sedimentary stock available at the beginning of the simulation, the skin roughness length, and the erosion constant. The skin roughness length is associated with sediment grain-size characteristics and used to estimate the threshold shear stress for the initiation of sediment motion. It differs from the bedform roughness length previously mentioned, which is used to take into account the effect of bedforms on flow (Le Hir, 2008).
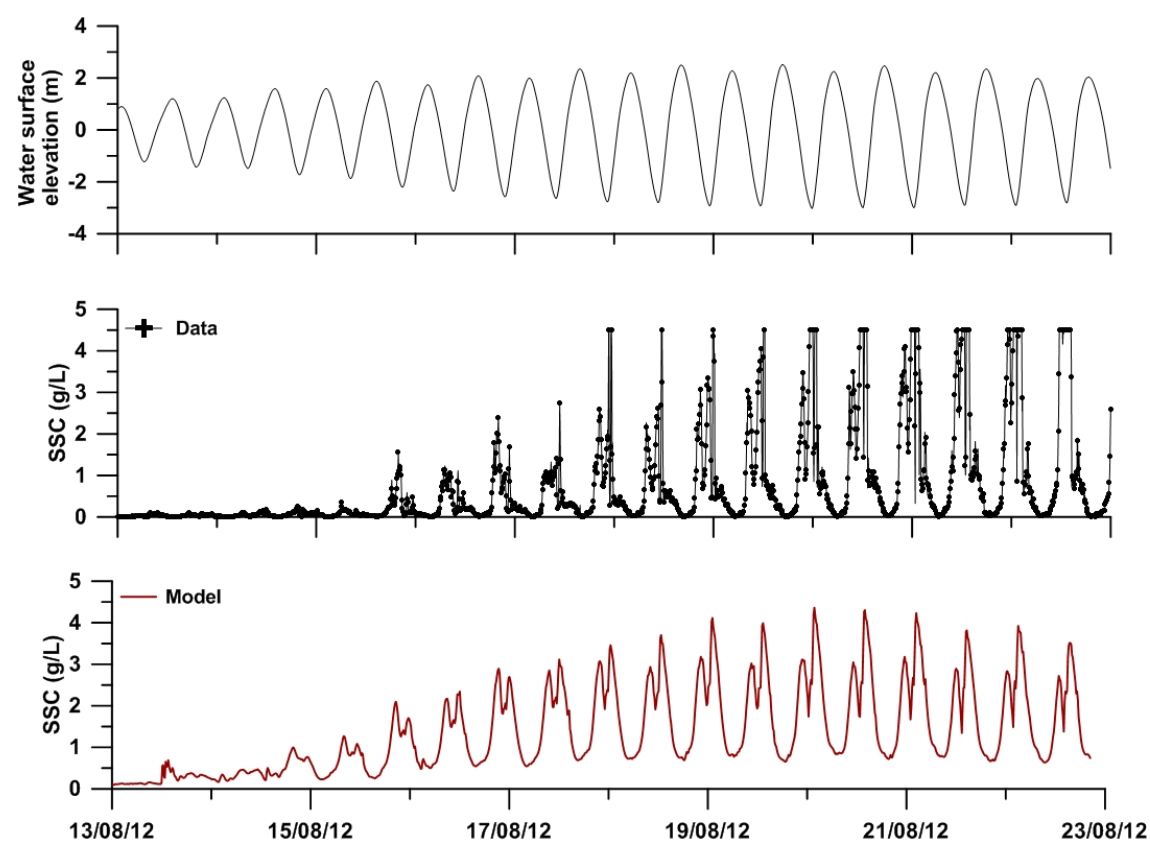

Figure 4: Measured (using a YSI probe) and modelled suspended sediment concentrations at the river mouth

Following this calibration/validation, the turbidity maximum is well reproduced by the model, and its position and movements are coherent with field observations. The background concentration is higher in the model than in observations. This difference could be explained by the tendency of numerical models in sigma coordinates to smooth the $S S C$, the volume integrated in the modelled cell being more important than the volume of the measurement cell (Sottolichio et al., 2014). A different tuning of the settling velocity could also improve the results, but the values for the maximum and minimum settling velocities were chosen to obtain satisfying results, both at the river mouth and at Rochefort. Higher $S S C$ are obtained during neap tides in the model. This period in the tidal cycle favours the 
presence of the fluid mud. As shown by Ross and Mehta (1989), density stratification caused by fluid mud and its interface with the water column (lutocline) can reduce mixing and suppress resuspension. This is not yet taken into account in the model and could explain the differences obtained during neap tides.

The skill parameter equals 0.62 at the river mouth and 0.74 at Rochefort. These results are within the range of those obtained in recent studies on 3D hydrosedimentary modelling of estuaries: Cheng et al. (2013) obtained skill values of 0.66 and 0.88 for surface and bottom $S S C$, respectively; Van Maren et al. (2015) obtained skill values greater than 0.6. Figure 4 shows that the order of magnitude of suspended sediment concentrations and the spring-neap variability are well reproduced. Particularly, the transition from neap to spring tides occurs gradually, following the same pattern as the observations. We also note that the ebb/flood asymmetry, which is a crucial feature in this study, is well-represented: during spring tide, the $S S C$ is higher during the flood than during the ebb, and the high water slack favours deposition more than the low water slack. Thus, the model is suitable for the study of sediment dynamics conducted here, because it reproduces well the two main timescales considered (semi-diurnal and spring-neap tidal cycles).

\subsection{Semi-diurnal variability}

In this section, the evolution of suspended sediment concentrations during a $12 \mathrm{~h}$ spring tidal cycle is presented. The river discharge is set at $50 \mathrm{~m}^{3} \cdot \mathrm{s}^{-1}$. Four indicators are used to discuss the modelling results: $\overline{S S C}$, which represents the mean suspended sediment concentration in the estuary (from the river mouth to the upstream limit of the domain); $\overline{\triangle S S C}$, the mean bottom-surface difference in $S S C$, which is used to evaluate the overall vertical $S S C$ stratification; $S S C_{\max }$, the spatial maximum suspended sediment concentration and $\triangle S S C_{\max }$, the spatial maximum bottom-surface difference in $S S C$. For the last two parameters, the distance from the estuary's mouth is also calculated. These values are extracted from the model at four times: low water, three hours after low water (or mid-flood), high water, and three hours after high water (or mid-ebb) (Table 2).

Table 2: Indicators $\overline{S S C}, \overline{\Delta S S C}, S S C_{\max }, \Delta S S C_{\max }(\mathrm{g} / L)$ and distances from the river mouth for $S S C_{\max }$ and $\Delta S S C$
\begin{tabular}{l|cccc}
\hline & Low water & Low water $+3 \mathrm{~h}$ & High water & High water $+3 \mathrm{~h}$ \\
\hline$\overline{S S C}$ & 3.78 & 2.41 & 1.21 & 0.620 \\
\hline$\overline{\Delta S S C}$ & 1.29 & 1.44 & 1.41 & 0.425 \\
\hline$S S C_{\max }$ & 9.07 & 9.80 & 14.7 & 2.87 \\
\hline Distance & -3.76 & 2.97 & 13.3 & 11.4 \\
\hline$\Delta S S C_{\max }$ & 5.27 & 8.24 & 14.4 & 2.26 \\
\hline Distance & -4.31 & 2.97 & 13.3 & 11.4 \\
\hline
\end{tabular}

The variations in $S S C$ are also shown in Figure 5. The results are displayed using a logarithmic colour scale to include the over the entire range of concentrations. This logarithmic scale is particularly important for the results 

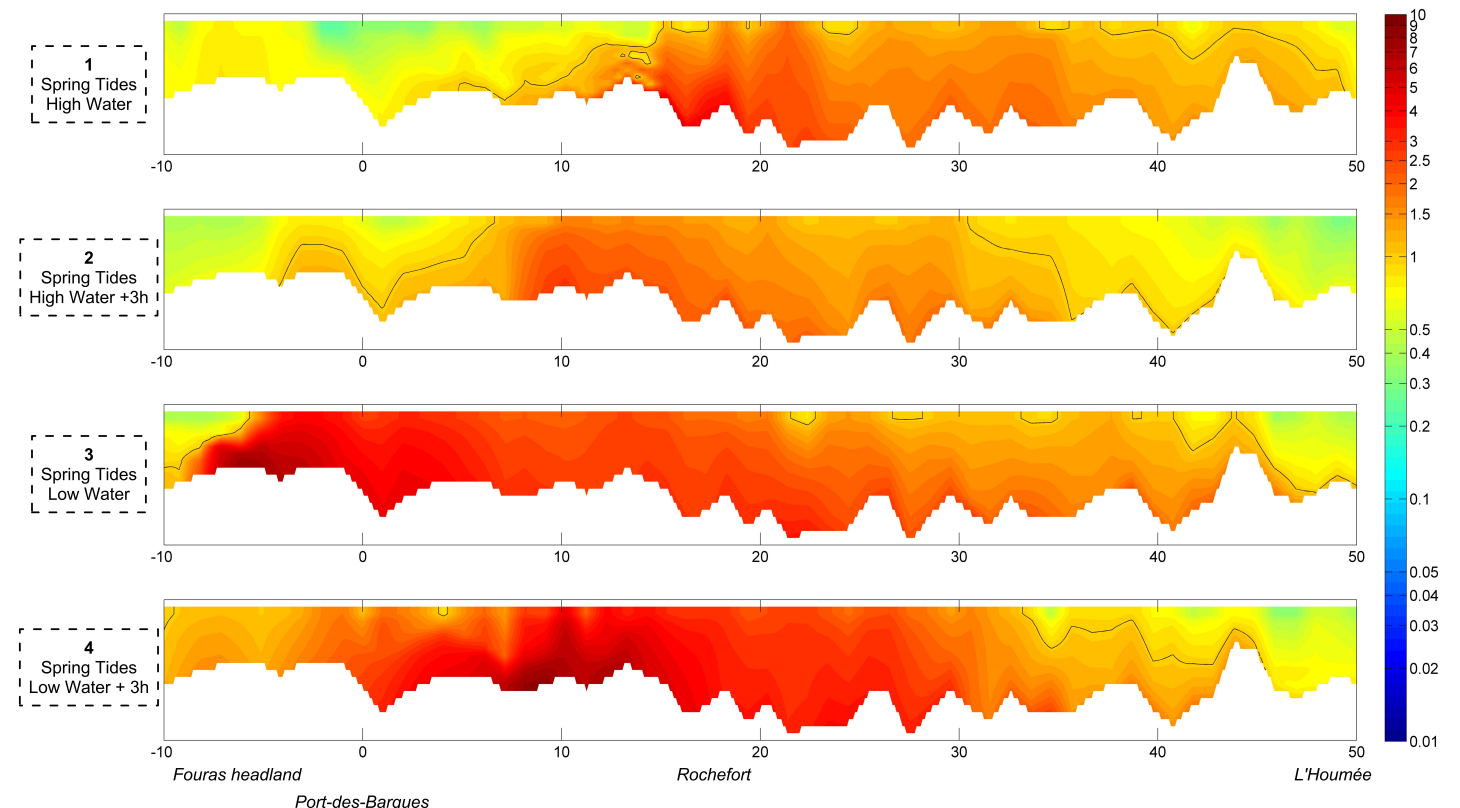

Distance from the river mouth $(\mathrm{km})$

Figure 5: Transects of modelled suspended sediment concentrations for a tidal cycle of spring tides and mean river discharge - The black line represents the $1 g / L$ contour

shown in the later sections, inclusind neap tides results. The contour line corresponding to a concentration of $1 \mathrm{~g} / \mathrm{L}$ is drawn in black and hereafter to denote the "limit" of the turbidity maximum.

At low water, the mean $S S C$ is close to $4 \mathrm{~g} / L$ and $\overline{\Delta S S C}$ is $1.29 \mathrm{~g} / \mathrm{L} . S S C_{\max }$ and $\triangle S S C_{\max }$ are both obtained approximately 4 kilometres downstream from the reference point chosen as the river mouth (see Figure 1). As the tidal cycle progresses, $\overline{S S C}$ decreases by more than $35 \%$ in 3 hours, while $\overline{\triangle S S C}$ remains stable. $S S C_{\max }$ and $\triangle S S C_{\max }$ are obtained $3 \mathrm{~km}$ upstream from the mouth, and their values increase between low water and mid-flood. Transects 3 and 4 (Figure 5) show that the turbidity maximum extension is close to $60 \mathrm{~km}$ and does not vary significantly. Suspended sediment concentrations remain high during this phase of the tidal cycle.

Between mid-flood and high water, the mean $S S C$ is halved. $\overline{S S C}$ is three times higher at low water than at high water. However, $\overline{\triangle S S C}$ remains nearly constant, suggesting that stratification is high. Strong $S S C_{\max }$ and $\triangle S S C_{\max }$ values (more than $14 \mathrm{~g} / \mathrm{L}$ ) that occur $13 \mathrm{~km}$ from the river mouth support this assumption. An overall decrease in $S S C$ is also observed in transect 1 (Figure 5), even though strong concentrations still exist close to the bottom. The turbidity maximum extension is almost $45 \mathrm{~km}$.

Between high water and mid-ebb, $\overline{S S C}$ is nearly halved, and $\overline{\triangle S S C}$ is reduced by $70 \%$. The $S S C$ and $\triangle S S C$ maxima reach their lowest values (Table 2). The difference in distance between high water and mid-ebb is $2 \mathrm{~km}$, compared to $7 \mathrm{~km}$ between low water and mid-flood. The turbidity maximum extension at mid-ebb (Transect 2 , Figure 5) is estimated to be between 35 and $40 \mathrm{~km}$. 
From mid-ebb to low water, mean $S S C$ and $\triangle S S C$ increase sixfold and threefold, respectively. Maximum values also increase and occur $15 \mathrm{~km}$ downstream from their mid-ebb location.

These results suggest that the most dynamic periods in the tidal cycle are the first hours of flood and the last hours of ebb. These periods are associated with strong increases in SSCs in the estuary, and with the highest differences in distance for $S S C_{\max }$ and $\Delta S S C_{\max }$. In contrast, from mid-flood to mid-ebb, suspended sediment concentrations decrease significantly.

\subsection{Spring-neap variability}

The indicators presented in the previous section $\left(\overline{S S C}, \overline{\Delta S S C}, S S C_{\max }\right.$ and $\left.\triangle S S C_{\max }\right)$ are extracted from modelling results and presented in Table 3, for spring and neap tides. $\overline{S S C}$ and $\overline{\Delta S S C}$ are calculated over two tidal cycles (approximately $24 \mathrm{~h}$ ). The corresponding distances from the mouth are indicated for $S S C_{\max }$ and $\Delta S S C_{\max }$, as well as the time in the tidal cycle when these values are reached. Figure 6 shows the distribution of $S S C$ for high and low water during spring and neap tides.

Table 3: The indicators $\overline{S S C}, \overline{\Delta S S C}, S S C_{\max }, \Delta S S C_{\max }(\mathrm{g} / L)$, and their associated distances from the mouth (km) and times during the tidal cycle at mean, high and low river discharge $\left(50 \mathrm{~m}^{3} / \mathrm{s}, 400 \mathrm{~m}^{3} / \mathrm{s}, 5 \mathrm{~m}^{3} / \mathrm{s}\right)$

\begin{tabular}{l|cc|cc|cc}
\hline & \multicolumn{2}{|c}{ Mean river discharge } & \multicolumn{2}{c}{ High river discharge } & \multicolumn{2}{c}{ Low river discharge } \\
\hline & Spring tides & Neap tides & Spring tides & Neap tides & Spring tides & Neap tides \\
\hline$\overline{S S C}$ & 1.63 & 0.183 & 1.29 & 0.307 & 1.22 & 0.091 \\
\hline$\overline{\Delta S S C}$ & 1.11 & 0.080 & 0.880 & 0.141 & 0.697 & 0.037 \\
\hline$S S C_{\max }$ & 14.7 & 1.81 & 12.0 & 2.74 & 5.58 & 1.14 \\
Distance & 13.3 & 29.8 & 3.09 & 22.1 & 11.7 & 22.3 \\
Tide hour & HW & LW & LW+3 & LW & LW+4 & HW+5 \\
\hline$\Delta S S C_{\max }$ & 14.4 & 1.44 & 10.6 & 2.22 & 4.21 & 0.887 \\
Distance & 13.3 & 29.8 & 1.64 & 22.1 & 12.2 & 22.3 \\
Tide hour & HW & LW & LW +3 & LW & LW+4 & HW+5 \\
\hline
\end{tabular}

The indicators $\overline{S S C}, S S C_{\max }$ and $\triangle S S C_{\max }$ are reduced by an order of magnitude between spring and neap tides. Maxima occur at high water during spring tides and at low water during neap tides. The $\overline{\Delta S S C}$ is less than $0.1 \mathrm{~g} / L$ during neap tides, and close to $1 \mathrm{~g} / \mathrm{L}$ during spring tides.

These values show a large reduction of the suspended sedimentary mass between spring and neap tides, which is also shown in Figure 6. The $1 \mathrm{~g} / \mathrm{L}$ contour line (in black) is non-existent during the high water period of neap tides and barely visible at low water (approximately $45 \mathrm{~km}$ from the river mouth). It appears to be difficult to define a turbidity maximum zone under these conditions. For spring tides, the highest $S S C s$ are obtained close to the downstream 

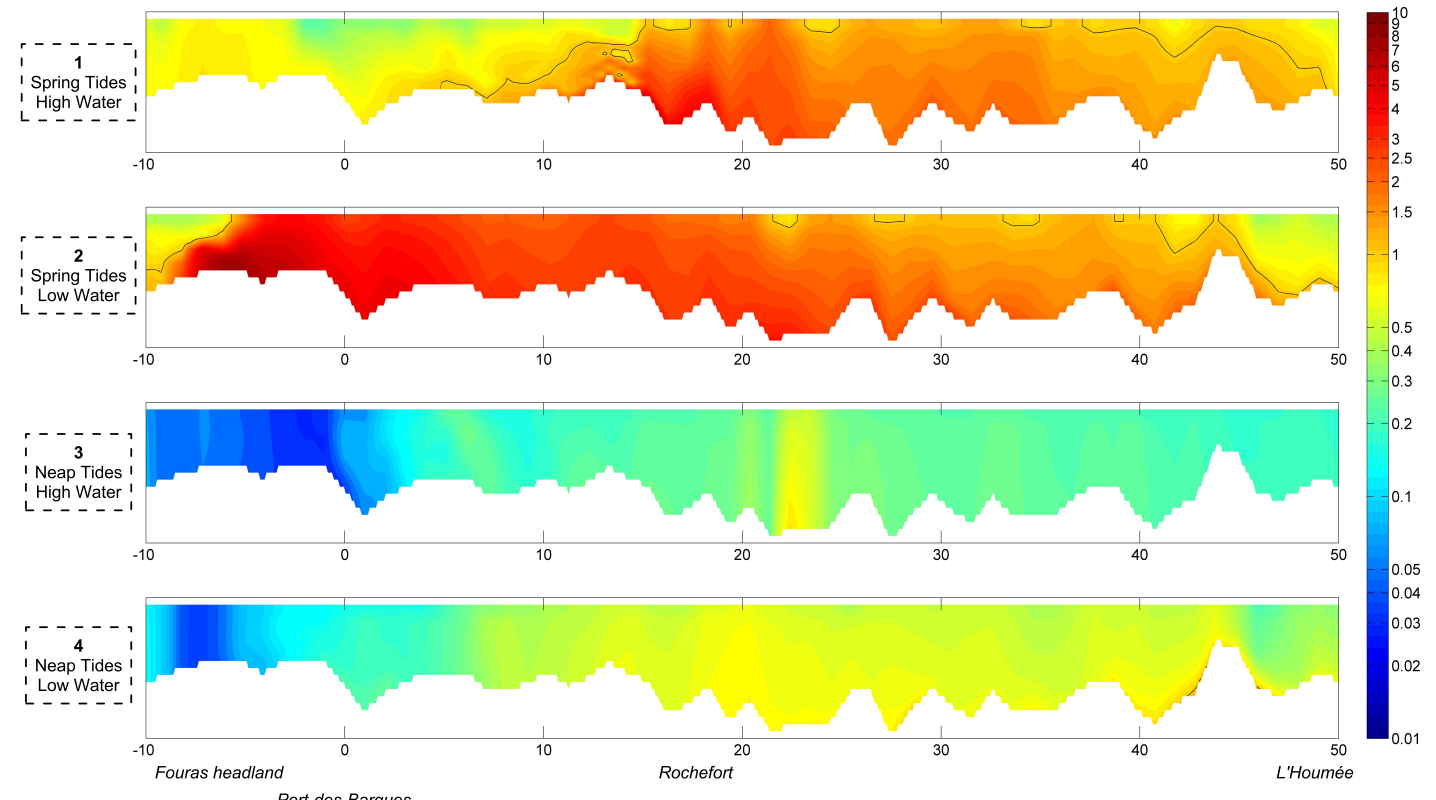

Port-des-Barques

Distance from the river mouth $(\mathrm{km})$

Figure 6: Transects of modelled suspended sediment concentrations for high and low water during spring and neap tides under mean river discharge. The black line indicates the $1 \mathrm{~g} / \mathrm{L}$ contour.

limit of the sedimentary mass in suspension. During neap tides, the highest concentrations occur in the middle of the estuary (approximately $22 \mathrm{~km}$ from the river mouth during high water) or further upstream (low water).

\subsection{Runoff variability}

To estimate the impact of river discharge on the turbidity maximum dynamics and characteristics, the same indicators are presented in Table 3, for a high runoff of $400 \mathrm{~m}^{3} / \mathrm{s}$ and a low runoff of $5 \mathrm{~m}^{3} / \mathrm{s}$. Figures 7 and 9 show the corresponding transects along the estuary, as in the previous sections.

\subsubsection{High runoff}

The spring tide mean $S S C$ decreases between the $50 \mathrm{~m}^{3} / \mathrm{s}$ and the $400 \mathrm{~m}^{3} / \mathrm{s}$ simulations (by more than $20 \%$ ). Similar results are obtained for $\overline{\Delta S S C}, S S C_{\max }$ and $\triangle S S C_{\max }$ (which decrease between $18 \%$ and 26\%). In contrast, during neap tide the $S S C$ increases by more than 50\% when the river runoff increases. Transects 3 and 4 (Figure 7) demonstrate this difference, especially at low water: while the $1 \mathrm{~g} / L$ contour line was almost non-existent in Figure 6, it is well defined in Figure 7.

The $S S C_{\max }$ and $\Delta S S C_{\max }$ both occur three hours after low water during spring tide (three hours sooner than mean runoff conditions), and relatively close to the mouth $(3.09 \mathrm{~km}$ and $1.64 \mathrm{~km}$, respectively). Both maxima occur $22 \mathrm{~km}$ from the river mouth during low water during neap tides (and at the same time as the mean runoff). 

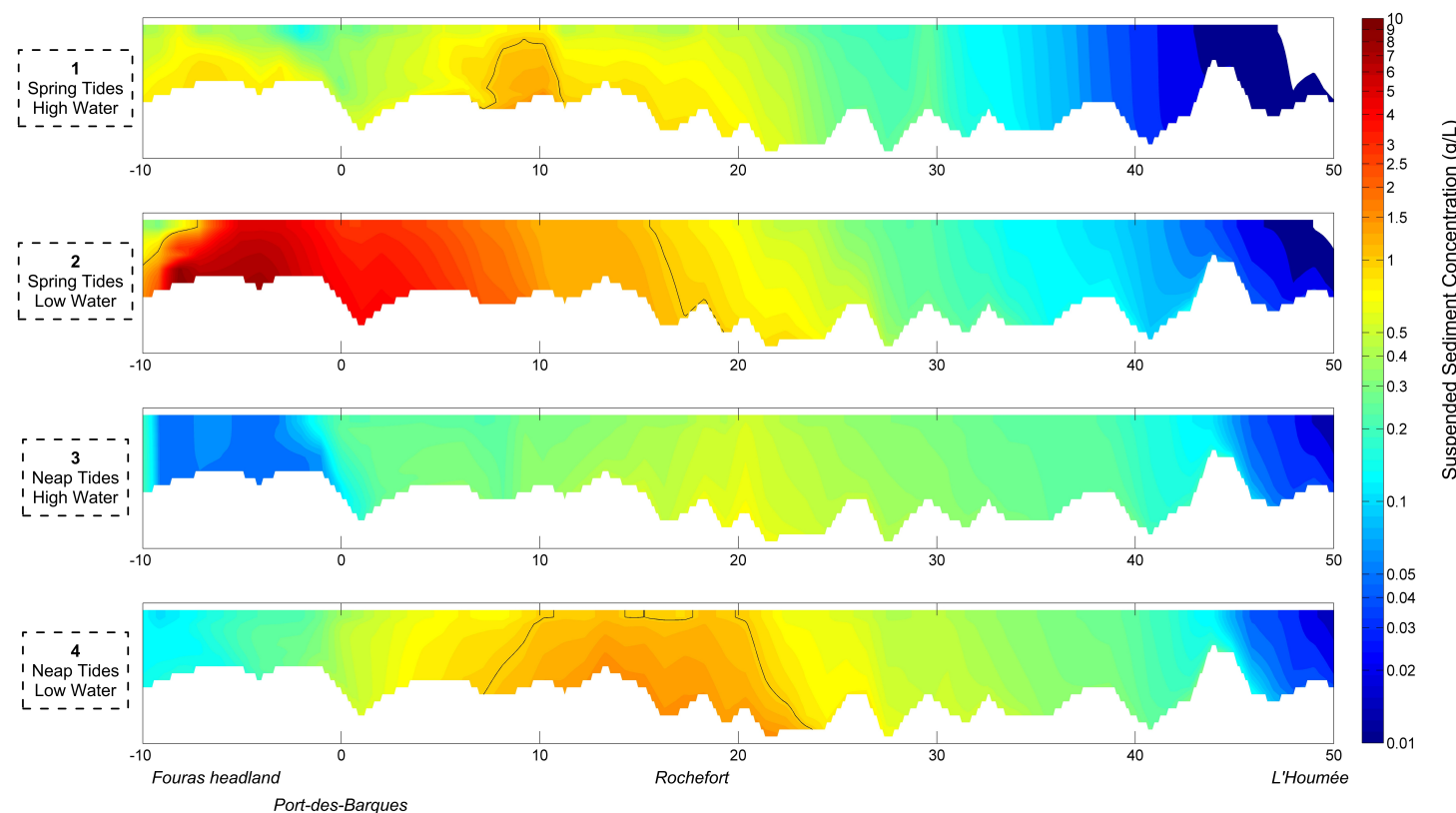

Distance from the river mouth $(\mathrm{km})$

Figure 7: Transects of modelled suspended sediment concentrations for high and low water during spring and neap tides under high river discharge. The black line indicates $1 \mathrm{~g} / \mathrm{L}$ contour.

The transects also show changes in the upstream area. At low water during spring tide, the turbidity maximum id denser, as shown by a downstream shift in the $1 \mathrm{~g} / \mathrm{L}$ contour line, and the maximum $S S C$ reaches $8.7 \mathrm{~g} / \mathrm{L}$, compared to $7.8 \mathrm{~g} / \mathrm{L}$ in mean runoff conditions. The extension of the turbidity maximum is close to $30 \mathrm{~km}$, compared to $60 \mathrm{~km}$ for the mean runoff simulation. The $S S C$ does not exceed $0.01 \mathrm{~g} / L$ at the most upstream position for all transects.

At low water during spring tides, the downstream "limit" of the turbidity maximum shifts seaward by a few kilometres. If the limit is considered to be point of maximum $S S C$, this constitutes a $2.1 \mathrm{~km}$ difference. However, the turbidity maximum does not seem to be fully advected from the estuary into the bay. SSC measurements confirm this behaviour (Figure 8): river discharge is increasing from $150 \mathrm{~m}^{3} / \mathrm{s}$ to $400 \mathrm{~m}^{3} / \mathrm{s}$ and $S S C$ decreases at Rochefort while it stays high at the river mouth. Moreover, $S S C$ values greater than $1 \mathrm{~g} / \mathrm{L}$ are recorded during neap tides.

\subsubsection{Low runoff}

Estuarine turbidity consistently decreases when the river runoff is very low $\left(5 \mathrm{~m}^{3} / \mathrm{s}\right)$. All of the values in the final two columns of Table 3 (representing low runoff conditions) are lower than those for mean runoff. The transects (Figure 9)confirm this behaviour graphically.

The SSC and $\triangle S S C$ maxima occur at different times during the tidal cycle: 4 hours after low water for spring tide and five hours after high water for neap tide. Positions and extensions are similar to those for mean river discharge. For high water during spring tides (Figure 9, transect 1), $S S C$ is however higher upstream during low runoff conditions. 


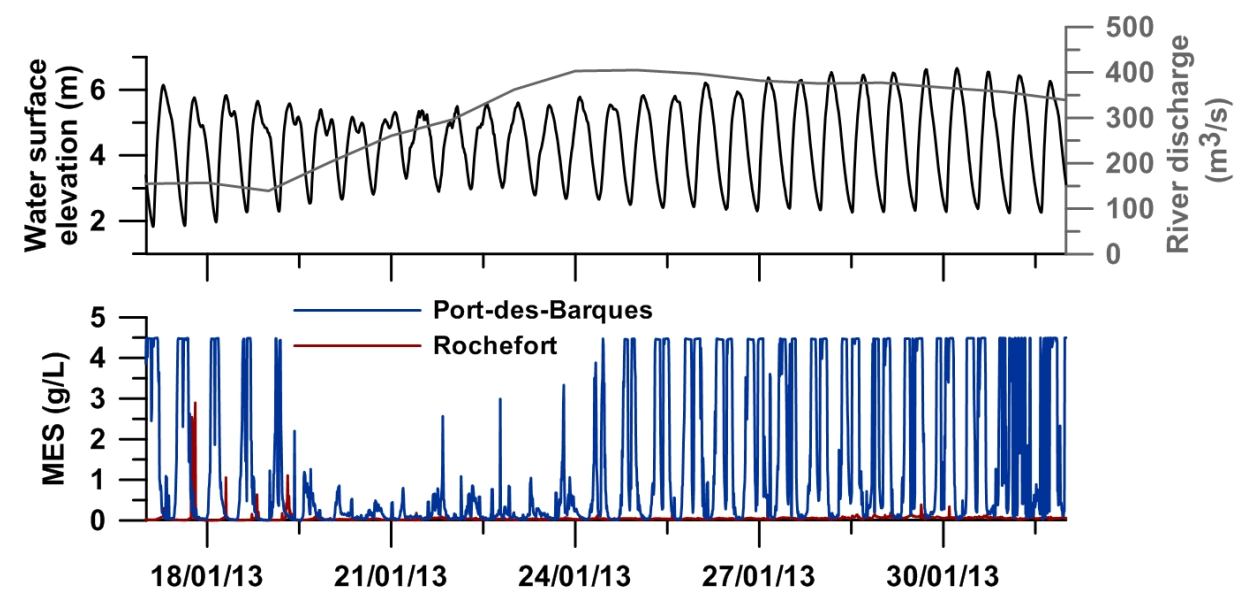

Figure 8: Observed SSC at the river mouth (Port-des-Barques) and Rochefort under flood conditions

During neap tide, the same remark made for mean runoff holds true for low runoff conditions: it is difficult to define a suspended sedimentary mass.

\section{Discussion}

\subsection{Flood/ebb variability: deposition and resuspension}

The semi-diurnal tidal cycle induces variations in current velocities, which directly impact the bed shear stress. Along with the nature and state of the sedimentary bed, bed shear stress is one of the parameters that control erosion processes (Mehta and Parchure, 2000; Tolhurst et al., 2000). The results of this study demonstrate the impact of these current variations on the turbidity maximum over a tidal cycle during spring tides.

The difference between high and low water slack is particularly important. The latter is short and current velocities remain high within the estuary (more than $1 \mathrm{~m} / \mathrm{s}$ ). Around high water, current velocities are weaker for a longer period of time, allowing sedimentation. This behaviour affects $S S C$ and $\triangle S S C$. The $\overline{S S C}$ is three times higher at low water that at high water.

At high water, the maximum $S S C$ is high (over $10 \mathrm{~g} / L$ ) and so is stratification. Calculating a stratification ratio $(\overline{\triangle S S C} / \overline{S S C})$ allows comparison between the results. This ratio is greater than 1 at high water, showing that suspended sediments are not well distributed throughout the water column; the transects in Figure 5 confirm this result. In contrast, the stratification ratio is 0.34 at low water. Three hours after high water (mid-ebb), $\overline{S S C}$ is halved, suggesting that deposition occurred for the last three hours, causing an overall decrease in estuarine $S S C$.

The $\overline{S S C}$ decreases between low water and mid-flood as well, but it remains higher than around high water: $\overline{S S C}$ is almost four times greater at mid-flood than at mid-ebb. This difference also suggests that deposition occurred, but for a shorter period of time. Sediments also begin to become resuspended due to the increase in current velocities, because $S S C_{\max }, \triangle S S C_{\max }$ and $\triangle S S C$ increase three hours after low water. The turbidity maximum extension, 

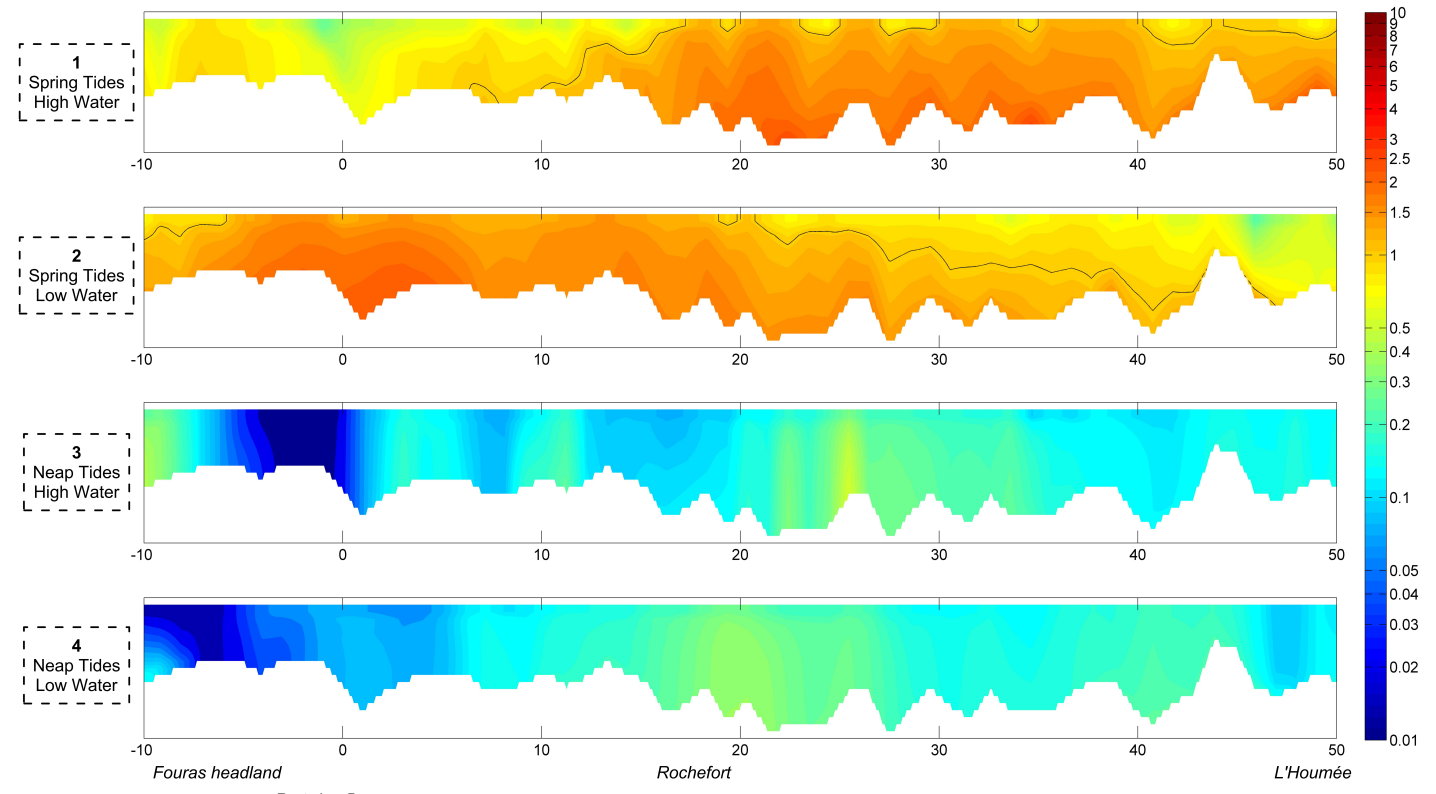

Port-des-Barques

Distance from the river mouth $(\mathrm{km})$

Figure 9: Transects of modelled suspended sediment concentrations for high and low water during spring and neap tides under low river discharge. The black line indicates the $1 \mathrm{~g} / \mathrm{L}$ contour.

defined by the $1 \mathrm{~g} / L$ limit, is greater at low water and mid-flood $(60$ to $55 \mathrm{~km}$ ) than at high water and mid-ebb (40 to $45 \mathrm{~km})$.

Sediments are maintained in suspension by strong velocities at the end of the ebb and at the beginning of the flood, making this period in the tidal cycle more dynamic than the high water slack. This behaviour has been observed in other estuaries including the Tamar, the Humber-Ouse (Uncles and Stephens, 1993; Uncles et al., 2006), the Gironde (Sottolichio, 1999) and the Seine (Brenon and Le Hir, 1999).

The $S S C$ variations in the Charente turbidity maximum are mainly driven by the successive phases of deposition, advection and resuspension, caused by current velocity fluctuations. Uncles et al. (1996) showed, that the turbidity maximum in the Tamar estuary primarily results from local resuspension, and that seasonal variability is partly due to the migration of mud deposits that move the bed-source of sediments. These observations can be transposed to the Charente estuary, where both the modelling results presented in this study and field measurements (Coulombier et al., 2013) show the same type of behaviour.

\subsection{Fortnightly and seasonal variability: does the turbidity maximum always exist?}

Results show a strong variability in the dynamics and characteristics of the turbidity maximum in the Charente estuary. The spring-neap tidal cycle and the fluctuations in river runoff cause significant variations in suspended sediment concentrations throughout the estuary. 
The mean $S S C$ decreases nearly ninefold between spring and neap tide. Bottom shear stress is significantly reduced during neap tide because of the decrease in current velocities. As shown in the previous section, these fluctuations strongly impact resuspension and deposition processes. Turbulence and tidal mixing keep sediments in suspension during spring tide, whereas weak neap tide currents favour sedimentation (Dyer, 1997).

For mean runoff, it is difficult to define a turbidity maximum during neap tides, because no clear high concentration area stands out. The maximum $S S C(1.8 \mathrm{~g} / \mathrm{L})$ occurs approximately $30 \mathrm{~km}$ upstream, at low water, and probably results from local resuspension due to bathymetric variations as opposed to tidal straining. Dual frequency echo sounding performed during average tidal conditions (Coulombier et al., 2013) showed the presence of a turbidity maximum, confirmed by high $S S C$ recorded from mid-depth to the bottom, meaning that the turbidity maximum was not extended throughout the water column. These observations testify of an intermediate state between spring and neap tide, when the turbidity maximum still exists but begins to weaken. In contrast, echo sounding performed during spring tide showed no interface in the water column with high SSC recorded throughout the water column and over the entire area covered during the survey (from the river mouth to approximately $5 \mathrm{~km}$ downstream from L'Houmée). Modelling results are coherent with these observations. In the Loire estuary, Marchand (1993) mentions that during neap tide, the turbidity maximum settles and induces the formation of a mud layer at the bottom, which can cover a large area (20 km in the case of the Loire). The dual frequency echo sounding mentioned before also showed a net interface near the bottom at Rochefort, interpreted as a fluid mud patch of high concentration, with a thickness reaching $1.5 \mathrm{~m}$ in the deepest part of the channel. Fluid mud at the bottom can significantly reduce friction and tidal dissipation, which was taken into account in our model. This phenomenon has also been observed at the Amazon outlet (Gabioux et al., 2005; Kineke et al., 1996). Other highly turbid macrotidal estuaries are likely to display this type of behaviour, and Marchand (1993) highlights its negative effect on water quality, which is essential to the ecology of these areas.

The same behaviour is observed for low runoff conditions (Figure 9), which often prevail during the summer; even lower concentrations exist in the water column (mean $S S C$ is less than $0.1 \mathrm{~g} / L$ and maximum $S S C$ is less than 1.5 $g / L)$. A shift in the time occurrence of maximum $S S C$ and $\triangle S S C$ is also observed. They occur one hour earlier during neap tide (five hours after high water), and two hours earlier during spring tide (four hours after low water). In the absence of significant river discharge, the sediment dynamics of the estuary are essentially driven by the tidal forcing. Toublanc et al. (2015) showed that tidal asymmetry inversions occur in the estuary, following the spring-neap tidal cycle. For spring tide, the estuary is flood-dominant (shorter flood, stronger flood velocities). During neap tide, it is ebb-dominant (shorter ebb, stronger ebb velocities). These inversions could explain the difference we find in this study, with higher $S S C$ during the ebb for neap tides, and higher $S S C$ during the flood for spring tides.

High runoff simulations show that a turbidity maximum can also appear during neap tide. The joint action of high river discharge and the tides leads to the formation and maintenance of a well-defined suspended sedimentary mass, with significant longitudinal SSC gradients, in contrast to the mean and low runoff simulations. During spring tide, $S S C_{\max }$ and $\triangle S S C_{\max }$ occur three hours earlier (mid-flood) than for the mean runoff simulation (high water). This 
difference can be explained by the tidal damping caused by a strong river discharge. Because the hours defined as for low and high water are extracted from predictions, they cannot reflect the shift in the estuarine dynamics due to runoff variability. As explained by Horrevoets et al. (2004), high runoff induce higher low water levels upstream, especially when the cross-section is narrow. Friction is modified and the estuarine flow is more quickly by the river discharge than for mean conditions. Godin (1985) indicated that in the downstream part of the estuary, low water will be slowed and high water will be accelerated. The three-hour shift observed during spring tide and high runoff conditions could correspond to this river discharge effect.

Although $S S C$ levels vary between the mean and low runoff simulations, the position and extension of the turbidity maximum between low and high water during spring tide are similar. These results suggest that, for this range of river discharge, turbidity maximum dynamics are mainly driven by the tides. In the following subsection, the relative importance of the tides and the density gradients are discussed further.

\subsection{Impact of density gradients on turbidity maximum characteristics}

Two principal mechanisms dictate the formation of a turbidity maximum in an estuary: tidal asymmetry and density circulation (Allen et al., 1980; Brenon and Le Hir, 1999; Uncles et al., 1998). The characteristics and dynamics of this sedimentary mass often result from the joint action of these two phenomena. Uncles and Stephens (1993) explain that the position of the turbidity maximum sometimes corresponds to the position of the saline intrusion, and varies according to changes in tidal and fluvial forcings. The transects for mean and high river runoff conditions (Figures 6 and 7) show that, even if the turbidity maximum shifts seaward when the runoff is high, it does not seem to be exported from the estuary.

Maintenance of the turbidity maximum within the limits of the estuary could be explained by interactions between this sedimentary structure and salinity gradients, which are also subject to variations in the tides and the river discharge. Figure 10 shows the $S S C$ along with modelled salinity levels for different tidal and fluvial conditions.

The saline intrusion limit, defined by the 1 psu contour line, is located upstream of the maximum $S S C$ zone for the mean runoff simulation. However, the downstream limit of $1 g / L$ corresponds to the area where the salinity levels change rapidly, i.e when the horizontal salinity gradient is stronger, especially at low water. Under a strong runoff, the saline intrusion moves downstream and the horizontal salinity gradient is stronger. The association with the turbidity maximum is clearer than for mean runoff conditions. Given these observations, we hypothesize that density gradients associated with the salinity variations play a crucial role in maintaining the turbidity maximum inside the estuary. In the Gironde estuary, according to Sottolichio et al. (2000), density gradients are essential to the stability of the turbidity maximum and prevent a massive export of sediments. Brenon and Le Hir (1999) showed that tidal influence is predominant in the Seine estuary, but that density gradients also play a significant role in shaping the structure of the turbidity maximum and keeping fine sediments in the estuary. The relative importance of both mechanisms was also studied by Allen et al. (1980) and Uncles et al. (1998), who consider that tidal asymmetry is predominant at low to mean runoff conditions and that sediment trapping strongly depends on density circulation at high runoff conditions. 


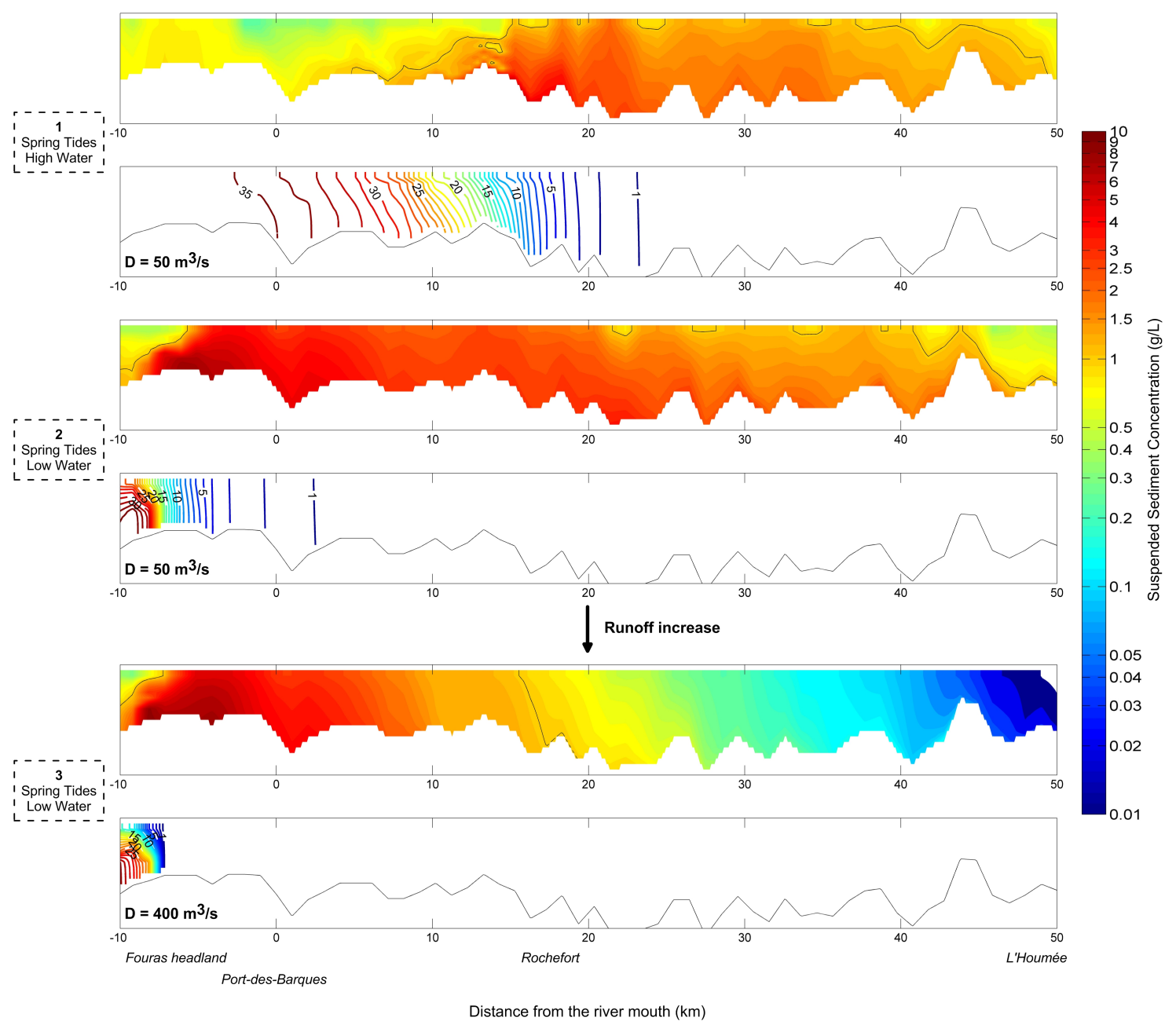

Figure 10: Transects of modelled suspended sediment concentrations and salinity for high and low water during spring tide under mean river discharge conditions ( $1 \& 2$ ) and for low water under high river discharge conditions (3). 
Simulations that do not consider the density gradients related to salinity are presented in Figure 11. The results show that even when the density gradients are not taken into account, the turbidity maximum stays within the estuary for both mean and high river runoff conditions. However, density gradients seem to play a significant role in defining the extension and concentration of the turbidity maximum. At low water, the downstream end of the turbidity maximum is sharper when density gradients are considered, and the longitudinal $S S C$ gradient is much stronger (3.75 $\mathrm{g} / \mathrm{L} / \mathrm{km}$ versus $1.25 \mathrm{~g} / \mathrm{L} / \mathrm{km}$ for the high runoff simulation).
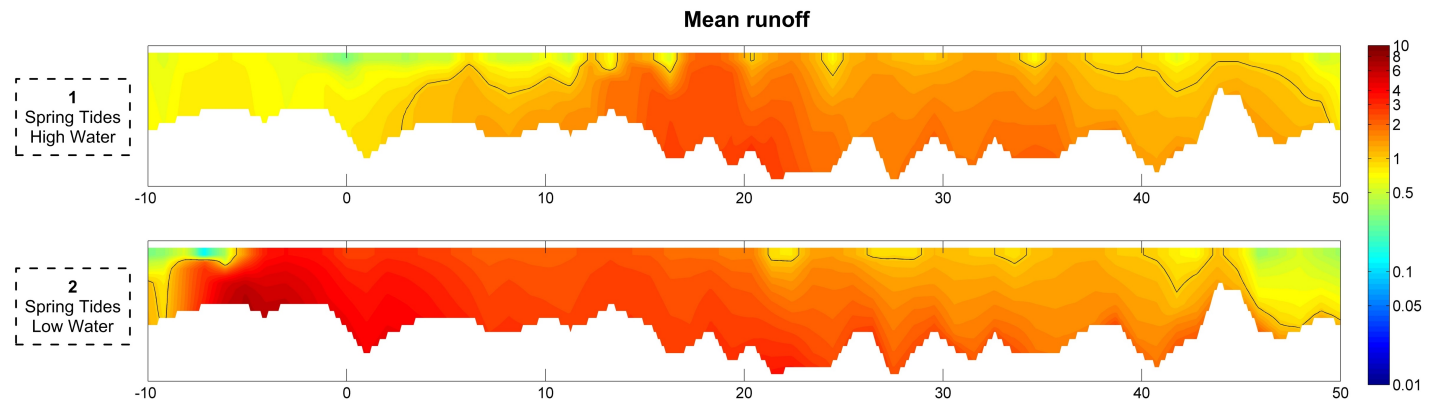

High runoff
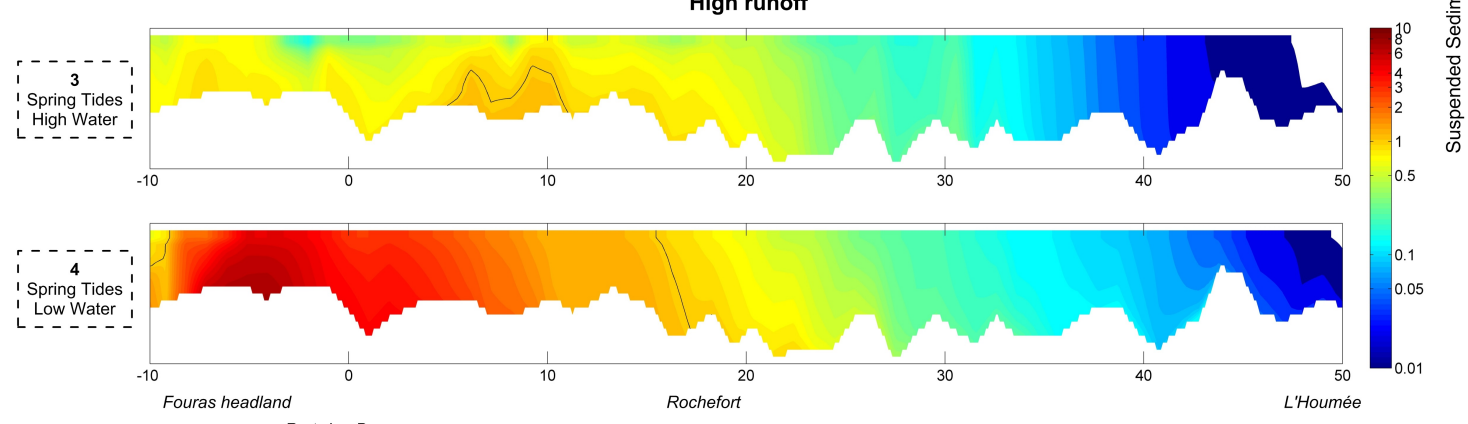

Port-des-Barques

Distance from the river mouth $(\mathrm{km})$

Figure 11: Transects of modelled suspended sediment concentrations for high and low water during spring tide, at mean (transects $1 \& 2$ ) and high (transects $3 \& 4$ ) river discharges. Density gradients are not taken into account.

Vertical density gradients also impact the structure of the turbidity maximum. For the mean runoff simulation, the downstream $1 \mathrm{~g} / \mathrm{L}$ limit is closer to the bottom when density gradients are considered, both at high and low water. Without these gradients, suspended sediments are better distributed throughout the water column, and the maximum concentrations are reduced. This behaviour is also observed for high runoff conditions. Figure 10 shows that salinity stratification is strong in this area, which reduces turbulent mixing and traps sediments near the bottom. This phenomenon was investigated and proved numerically by Geyer (1993) and Burchard and Baumert (1998). Blake et al. (2001) observed the same behaviour in the ACE Basin.

As in other macrotidal and/or highly turbid estuaries (Gironde,(Sottolichio et al., 2000); Humber-Ouse, (Uncles et al., 1998, 2006) and Seine (Brenon and Le Hir, 1999)), tidal asymmetry is the dominant mechanism leading to the formation of a turbidity maximum, but its structure and sediment trapping inside the estuary also depend on density 
circulation.

\section{Conclusion}

The Charente estuary is a highly turbid macrotidal system characterized by strong $S S C$ variations throughout the semi-diurnal and the spring-neap tidal cycles. River discharge also strongly influences $S$ S C.

The results of this study show that tidal forcing dominantly governs the dynamics and characteristics of the turbidity maximum in the Charente estuary. Resuspension and deposition cycles are the main source and sink for suspended sediments. Conditions during spring tide ensure that sediments are eroded and trapped in a highly turbid area for all river runoff situations. However, weak neap tide currents are insufficient to maintain a well-defined sedimentary mass in suspension. In this case, the river discharge can play a key role in the formation of the turbidity maximum; when runoff is high, a compact suspended sedimentary mass is obtained. Under low and mean runoff during neap tide, strong sedimentation is likely to induce the formation of a fluid mud layer at the bottom, or to reinforce is presence.

The turbidity maximum is not advected out of the estuary during high runoff conditions. Simulations without density gradients show that the core of the turbidity maximum remains within the estuary, although its structure and stability are significantly modified. The downstream end of the suspended sedimentary mass is less sharp, which could lead to greater sediment export, especially at low water during spring tides. Preliminary sediment fluxes results suggest a $12 \%$ net sediment export increase, after a 14 day simulation. Sediments are also more distributed throughout the water column, suggesting that vertical density stratification traps sediment at the bottom. Thus, tidal asymmetry is mostly responsible for the formation of the turbidity maximum, but density gradients help define its shape and the vertical and longitudinal SSC stratifications.

Bed consolidation was not taken into account in the model and is a perspective for future research. This mechanism could be particularly important for the transition between neap and spring tides. As mentioned before, neap tides favour sedimentation, generating deposits that may not be resuspended for several days. In this situation, consolidation could occur, making it more difficult for currents to erode sediments during the neap to spring transition. The impact of fluid mud also merits further investigation. For this study, friction does not vary through time. The development of coupling between deposits and the roughness length could be considered to improve model performance. Moreover, the reduction of mixing caused by density stratification in the lutocline could favour the stabilisation of fluid mud and suppress resuspension. Future developments of sediment component of the model could include this phenomenon.

\section{Acknowledgments}

The authors gratefully acknowledge funding from the Conseil Général of Charente Maritime, the Poitou-Charentes Region, the CNRS, the FEDER and the University of La Rochelle. We also acknowledge the REFMAR portal for the tide gauge data provided, as well as Ifremer for bathymetry and the MARS-3D code. 


\section{Appendix A. Sediment dynamics modelling}

The sediment module implemented in MARS-3D solves an advection/diffusion equation, taking into account erosion and deposition processes. A full description is available in previously cited studies (Le Hir et al., 2001; Le Hir et al., 2011). A brief summary follows.

For pure mud, the erosion law of Partheniades-Ariathurai is chosen to calculate the erosion flux:

$$
E_{\text {mud }}=E_{0, \text { mud }}\left(\frac{\tau}{\tau_{\text {cem }}}-1\right)
$$

$\tau_{c e m}$ is the critical shear stress for erosion and $E_{0, \text { mud }}$ is a constant.

The deposition flux is following the Krone law:

$$
D=W_{s} C\left(\frac{1-\tau}{\tau_{c d}}\right)
$$

$\tau_{c d}$ is the critical shear stress for deposition, $C$ is the suspended sediment concentration, and $W_{s}$ is the settling velocity. $W_{s}$ is determined through a semi-empirical relationship with $C$ (Le Hir et al., 2001), to take into account flocculation processes:

$$
\begin{gathered}
W_{s}=W_{\min }\left(1+\alpha_{1} C+\alpha_{2} C^{2}\right) \text { if } C \leq C_{W_{\max }} \\
W_{s}=\left(1-\beta_{1} C^{\beta_{2}}\right)^{4.65} R \text { if } C_{W_{\max }}<C \leq C_{W_{c r}} \\
R=\frac{W_{\min }\left(1+\alpha_{1} C_{W_{\max }}+\alpha_{2} C_{W_{\max }}^{2}\right)}{\left(1-\beta_{1} C_{W_{\max }}^{\beta_{2}}\right)^{4.65}}
\end{gathered}
$$

$W_{\min }$ and $W_{\max }$ are the minimum and maximum settling velocities, respectively. $C_{W_{\max }}$ is the concentration at which $W_{s}=W_{\max } . \alpha_{1}$ and $\alpha_{2}$ are constants chosen to reach a given maximum settling velocity at $C_{W_{\max }}$. Beyond this value of $C$, hindered settling velocity occurs. $\beta_{1}$ and $\beta_{2}$ are chosen to take into account this behaviour. $C_{W_{c r}}$ is a critical value of concentration, which corresponds conceptually to the gel point (concentration from which the water-sediment mixture is classified as fluid mud). Turbulence is also taken into account according to Van Leussen (1994).

\section{References}

Allen, G. P., Castaing, P., 1973. Suspended sediment transport from the Gironde estuary (France) onto the adjacent continental shelf. Marine Geology 14 (5), 47-53.

Allen, G. P., Salomon, J. C., Bassoullet, P., Penhoat, Y. D., de Grandpré, C., 1980. Effects of tides on mixing and suspended sediment transport in macrotidal estuaries. Sedimentary Geology 26 (1-3), 69-90.

Aubrey, D. G., Speer, P. E., 1985. A study of non-linear tidal propagation in shallow inlet / estuarine systems part I : observations. Estuarine, Coastal and Shelf Science 21, 185-205. 
Auguet, J. C., Montanie, H., Delmas, D., Hartmann, H., Huet, V., 2005. Dynamic of virioplankton abundance and its environmental control in the Charente Estuary (France). Microbial Ecology 50 (3), 337-349

Bertin, X., Bruneau, N., Breilh, J.-F., Fortunato, A. B., Karpytchev, M., 2012. Importance of wave age and resonance in storm surges: The case Xynthia, Bay of Biscay. Ocean Modelling 42, 16-30.

Bertin, X., Chaumillon, E., Sottolichio, A., Pedreros, R., 2005. Tidal inlet response to sediment infilling of the associated bay and possible implications of human activities: the Marennes-Oléron Bay and the Maumusson Inlet, France. Continental Shelf Research 25 (9), $1115-1131$.

Blake, A., Kineke, G., Milligan, T., Alexander, C., 2001. Sediment trapping and transport in the ACE Basin, South Carolina. Estuaries 24 (5), $721-733$.

Brenon, I., Le Hir, P., 1999. Modelling the turbidity maximum in the Seine estuary (France): Identification of Formation Processes. Estuarine, Coastal and Shelf Science 49 (4), 525-544.

Burchard, H., Baumert, H., 1998. The formation of estuarine turbidity maxima due to density effects in the salt wedge. A hydrodynamic process study. Journal of Physical Oceanography 28 (2), 309-321.

Cancino, L., Neves, R., 1999. Hydrodynamic and sediment suspension modelling in estuarine systems Part II : Application to the Western Scheldt and Gironde estuaries. Journal of Marine Systems 22, 117-131.

Cheng, P., Li, M., Li, Y., 2013. Generation of an estuarine sediment plume by a tropical storm. Journal of Geophysical Research 118 , 856-868.

Coulombier, T., Toublanc, F., Brenon, I., 2013. Seasonal monitoring of sediments dynamics in a highly turbid estuary (Charente Estuary, France): source and sink of the turbidity maximum. In: Proceedings of the 7th International Conference on Coastal Dynamics. pp. 387-396.

Dyer, K., 1997. Estuaries: a Physical Introduction. Wiley, London.

Eyre, B., McConchie, D., 1993. Implications of sedimentological studies for environmental pollution assessment and management : examples from fluvial systems in North Queensland and Western Australia. Sedimentary Geology 85, 235-252.

French, J., 2010. Critical perspectives on the evaluation and optimization of complex numerical models of estuary hydrodynamics and sediment dynamics. Earth Surface Processes and Landforms 35 (2), 174-189.

Friedrichs, C., Aubrey, G., 1988. Non-linear tidal distortion in shallow estuaries : a synthesis. Estuarine, Coastal and Shelf Science $27,521-545$.

Gabioux, M., Vinzon, S. B., Paiva, A. M., 2005. Tidal propagation over fluid mud layers on the Amazon shelf. Continental Shelf Research 25 (1), $113-125$.

Geyer, W. R., 1993. The importance of suppression of turbulence by stratification on the estuarine turbidity maximum. Estuaries 16 (1), 113 .

Godin, G., 1985. Modification of river tides by the discharge. Journal of waterway, port, coastal, and ocean engineering 111 (2), $257-274$.

Hamm, L., Walther, R., 2009. Morphodynamic coupling of bottom roughness and fluid mud for modelling tidal propagation in the Loire estuary (France). In: 31st Coastal Engineering Conference. pp. 1-11.

Horrevoets, A., Savenije, H., Schuurman, J., Graas, S., 2004. The influence of river discharge on tidal damping in alluvial estuaries. Journal of Hydrology 294 (4), 213-228.

Kineke, G. C., Sternberg, R. W., Trowbridgei, J. H., 1996. Fluid-mud processes on the Amazon continental shelf. Continental Slef Research $16(5-6), 667-696$

King, B., Wolanski, E., 1996. Bottom friction reduction in estuaries. Mixing in Estuaries and Coastal Seas 50, $325-337$.

Lazure, P., Dumas, F., 2008. An external-internal mode coupling for a 3D hydrodynamical model for applications at regional scale (MARS). Advances in Water Resources 31 (2), 233-250.

Le Cann, B., 1990. Barotropic tidal dynamics of the Bay of Biscay shelf. Continental Shelf Research 10 (8), $723-758$.

Le Hir, P., 2008. Aide mémoire de dynamique sédimentaire. Tech. rep., Ifremer.

Le Hir, P., Bassoullet, P., Jestin, H., 2001. Application of the continuous modeling concept to simulate high-concentration suspended sediment in a macrotidal estuary. Proceedings in Marine Science 3, 229-247.

Le Hir, P., Cayocca, F., Waeles, B., 2011. Dynamics of sand and mud mixtures: A multiprocess-based modelling strategy. Continental Shelf Research 31 (10), S135-S149.

Le Moine, O., Robert, S., Geairon, P., Chabirand, J.-M., 2012. Estuaire Charente : Flux à Saint- Savinien et intrusions salines, résultats durant 
l'étiage 2011. Tech. rep., Ifremer.

Le Roy, R., Simon, B., 2003. Réalisation et validation d'un modèle de marée en Manche et dans le Golfe de Gascogne. Application à la réalisation d'un nouveau programme de réduction des sondages bathymétriques. In: Rapport technique, EPSHOM, Rapport n002/03.

Li, M., Zhong, L., Boicourt, W. C., 2005. Simulations of Chesapeake Bay estuary: Sensitivity to turbulence mixing parameterizations and comparison with observations. Journal of Geophysical Research 110 (C12), C12004.

Li, Z., 1994. Modélisation numérique du transport des sédiments remis en suspension dans un estuaire - Application à la Gironde. Ph.D. thesis, Université Paris 06.

Ma, G., Shi, F., Liu, S., Qi, D., 2011. Hydrodynamic modeling of Changjiang Estuary: Model skill assessment and large-scale structure impacts. Applied Ocean Research 33 (1), 69-78.

Marchand, J., 1993. The influence of seasonal salinity and turbidity maximum variations on the nursery function of the Loire estuary (France). Netherlands Journal of Aquatic Ecology 27 (2-4), 427-436.

Mehta, A., Parchure, T., 2000. Surface erosion of fine-grained sediment revisited. In: Flemming, B., Delafontaine, M., Liebezeit, G. (Eds.), Muddy coast dynamics and ressource management. Elsevier, Amsterdam.

Mellor, G. L., Yamada, T., 1974. A hierarchy of turbulence closure models for planetary boundary layers. Journal of the Atmospheric Sciences 31, 1791-1806.

Mellor, G. L., Yamada, T., 1982. Development of a turbulence closure model for geophysical fluid problems. Reviews of geophysics and space physics $20(4), 851-875$

Milligan, T., Kineke, G., Blake, A., Alexander, C., Hill, P., 2001. Flocculation and sedimentation in the ACE Basin, South Carolina. Estuaries 24 (5), 734-744

Milligan, T. G., Hill, P. S., Law, B. A., 2007. Flocculation and the loss of sediment from the Po River plume. Continental Shelf Research 27, 309-321.

Modéran, J., David, V., Bouvais, P., Richard, P., Fichet, D., 2012. Organic matter exploitation in a highly turbid environment: Planktonic food web in the Charente estuary, France. Estuarine, Coastal and Shelf Science 98, 126-137.

Nikuradse, J., 1950. Laws of flow in rough pipes. National Advisory Committee for Aeronautics Washington.

Owens, P. N., Batalla, R. J., Collins, a. J., Gomez, B., Hicks, D. M., Horowitz, a. J., Kondolf, G. M., Marden, M., Page, M. J., Peacock, D. H., Petticrew, E. L., Salomons, W., Trustrum, N. a., 2005. Fine-grained sediment in river systems: environmental significance and management issues. River Research and Applications 21 (7), 693-717.

Ravail, B., Heral, M., Maestrini, S., Robert, J.-M., 1988. Incidence du débit de la Charente sur la capacité biotique du bassin ostréicole de Marennes-Oléron. Journal de Recherche Océanographique 13, 48-52.

Ross, M., Mehta, A., 1989. On the mechanics of lutoclines and fluid mud. Journal of Coastal Research (SI 5), 51-62.

Schmidt, S., Maneux, E., Dabrin, A., Oggian, G., Derriennic, H., Blanc, G., 2010. Impact d'un barrage intra-estuarien sur la dynamique sédimentaire : la retenue de Saint-Savinien (Charente-Maritime). In: XIèmes Journées Nationales Génie Côtier - Génie Civil. Editions Paralia, pp. 405-414.

Smagorinsky, J., 1963. General circulation experiments with the primitive equations I: The basic experiment. Monthly Weather Review 91 (3), 99-164.

Sottolichio, A., 1999. Modélisation de la dynamique des structures turbides (bouchon vaseux et crème de vase) dans l'estuaire de la Gironde. Ph.D. thesis, Université Bordeaux 1.

Sottolichio, A., Hanquiez, V., Van Maanen, B., Arriagada, J., Jalon Rojas, I., Schmidt, S., Birrien, F., Bordeaux, U. D., Epoc, L., Pessac, F., 2014. Evolution hydrosédimentaire récente de l'estuaire de la Gironde. Apport d'un modèle de transport. In: XIIIèmes Journées Nationales Génie Côtier - Génie Civil. pp. 505-512.

Sottolichio, A., Hir, P. L., Castaing, P., 2000. Modeling mechanisms for the stability of the turbidity maximum in the gironde estuary, france. Proceedings in Marine Science 3, 373-386.

Strady, E., Kervella, S., Blanc, G., Robert, S., Yves Stanisière, J., Coynel, A., Schäfer, J., 2011. Spatial and temporal variations in trace metal 
concentrations in surface sediments of the Marennes Oléron Bay. Relation to hydrodynamic forcing. Continental Shelf Research 31 (9), 9971007.

Tesson, M., 1973. Aspects dynamiques de la sédimentation dans la baie de Marennes-Oléron (France). Ph.D. thesis, Bordeaux 1.

Tolhurst, T., Black, K., Paterson, D., Mitchener, H., Termaat, G., Shayler, S., 2000. A comparison and measurement standardisation of four in situ devices for determining the erosion shear stress of intertidal sediments. Continental Shelf Research 20 (10-11), 1397-1418.

Toublanc, F., Brenon, I., Coulombier, T., Le Moine, O., 2015. Fortnightly tidal asymmetry inversions and perspectives on sediment dynamics in a macrotidal estuary (Charente, France). Continental Shelf Research 94, 42-54.

Uncles, R., Stephens, J. A., 1993. The freshwater-saltwater interface and its relationship to the turbidity maximum in the Tamar estuary, United Kingdom. Estuaries 16 (1), 126-141.

Uncles, R. J., Barton, M. L., Stephens, J. A., 1996. Seasonal variability of mobile mud deposits in the Tamar Estuary. Mixing in Estuaries and Coastal Seas 50, 374-387.

Uncles, R. J., Easton, A. E., Griffiths, M. L., Harris, C., Howland, R. J. M., King, R. S., Morris, A. W., Plummer, D. H., 1998. Seasonality of the turbidity maximum in the Humber-Ouse estuary, UK. Marine Pollution Bulletin 37 (3-7), 206-215.

Uncles, R. J., Stephens, J. A., Harris, C., 2006. Runoff and tidal influences on the estuarine turbidity maximum of a highly turbid system : the upper Humber and Ouse Estuary, UK. Marine Geology 235, 213-228.

Van Leussen, W., 1994. Estuarine macroflocs and their role in fine-grained sediment transport. Ph.D. thesis, Universiteit van Utrecht.

Van Maren, D. S., Winterwerp, J. C., Vroom, J., 2015. Fine sediment transport into the hyper-turbid lower Ems River : the role of channel deepening and sediment-induced drag reduction. Ocean Dynamics 65, 589-605.

Walther, R., Bertrand, O., Rieu, J., Hamm, L., 2007. Modélisation tridimensionnelle de la salinité et de la turbidité dans l'estuaire de la Loire : couplage des processus. La Houille Blanche 4, 47-55.

Warner, J. C., Geyer, W. R., Lerczak, J. A., 2005a. Numerical modeling of an estuary: A comprehensive skill assessment. Journal of Geophysical Research 110 (C5), C05001.

Warner, J. C., Sherwood, C. R., Arango, H. G., Signell, R. P., 2005b. Performance of four turbulence closure models implemented using a generic length scale method. Ocean Modelling 8, 81-113.

Willmott, C. J., 1981. On the validation of models. Physical Geography 2 (2), 184-194.

Winterwerp, J., Van Kesteren, W., 2004. Introduction to the physics of cohesive sediment dynamics in the marine environment. Elsevier.

Xing, Y., Ai, C., Jin, S., 2012. A three-dimensional hydrodynamic and salinity transport model of estuarine circulation with an application to a macrotidal estuary. Applied Ocean Research 39, 53-71. 